\title{
KARAKTER FISIOLOGI LATEKS DAN HUBUNGANNYA DENGAN PRODUKSI LATEKS KLON GT 1 DI KEBUN KARET RAKYAT KABUPATEN LANGKAT
}

\author{
Physiological Character of Latex and Its Relationship to GT 1 Latex Productivity at \\ Rubber Smallholder in Langkat District
}

Yayuk PURWANINGRUM* dan Yenni ASBUR

Departemen Agroteknologi, Fakultas Pertanian Universitas Islam Sumatera Utara

Jalan Karya Wisata Gedung Johor, Medan 20144, Sumatera Utara

*E-mail : yayuk.purwaningrum@fp.uisu.ac.id

Diterima : 13 Juni 2019 / Disetujui : 25 Juni 2019

\begin{abstract}
Sucrose levels, inorganic phosphate, and thiol are physiological characteristics of rubber plants that are closely related to the ability of plants to produce latex. This study aimed to determine the correlation between physiological characters and latex production of GT1 clone latex, and the timing of proper stimulant application without disturbing the health of rubber plants. The research was carried out in smallholder rubber plantations, Which located in Harapan Village, Sei Lapang, Langkat District, North Sumatera Province and Physiology Laboratory of Sungei Putih Research Institute. The clones tested in this study was GT1 clone at the age of 20 years. This study used the method of statistical analysis Correlation and Regression Test. Based on statistical analysis. The results of correlation analysis showed that sucrose levels was negatively correlated with latex production, where high sucrose levels of low latex production was the opposite. In June the production of high latex was influenced by physiology of latex as much as $57.25 \%$. This condition was determined as appropriate time for stimulant application on GT 1 clone.
\end{abstract}

Keywords: Hevea brasiliensis; phosphate inorganic; sucrose; thiol

\footnotetext{
Abstrak

Kadar sukrosa, fosfat anorganik, dan thiol merupakan karakter fisiologi pada tanaman karet yang erat hubungannya
}

dengan kemampuan tanaman dalam pembentukan lateks. Tujuan dari penelitian ini adalah untuk mengetahui korelasi antara karakter fisiologi dengan produksi lateks pada klon GT 1 dan waktu aplikasi stimulan yang tepat tanpa mengganggu kesehatan tanaman karet. Penelitian ini dilaksanakan di kebun karet rakyat Desa Harapan, Kecamatan Sei Lapang, Kabupaten Langkat Sumatera Utara dan Laboratorium Fisiologi Balai Penelitian Sungei Putih pada tahun 2018. Klon yang diuji dalam penelitian ini yaitu klon GT 1 pada umur 20 tahun. Penelitian ini menggunakan metode Analisis Statistik Uji Korelasi dan Regresi. Berdasarkan analisis statistik hasil analisis korelasi menunjukkan bahwa kadar sukrosa berkorelasi negatif dengan produksi lateks. Bulan Juni produksi lateks tinggi dipengaruhi oleh faktor fisiologi lateks sebesar 57,25\%. Kondisi tersebut merupakan waktu yang tepat untuk aplikasi stimulansia pada klon GT 1.

Kata kunci: Fosfat anorganik; Hevea brasiliensis; sukrosa; thiol

\section{PENDAHULUAN}

Klon GT1 merupakan salah satu dari klon yang tergolong ke dalam low metabolism (LM), klon anjuran untuk perkebunan rakyat maupun perkebunan besar (Siregar et al., 2008). Klon ini responsif terhadap pemberian stimulan dan mencapai puncak produksi pada periode pertengahan siklus ekonomi yaitu 12-14 tahun. Produksinya dapat mencapai $2200-3000 \mathrm{Kg} / \mathrm{Ha} /$ tahun 
dan relatif lebih tahan terhadap tekanan eksploitasi tinggi jika kondisi agroekosistem sesuai (Sumarmadji, 2011).

Kestabilan produksi lateks suatu kebun dalam jangka waktu panjang dijaga dengan penanaman klon LM dan high metabolism (HM) secara bersamaan dengan komposisi yang seimbang. Komposisi yang seimbang yang dimaksud adalah karakter antar kelompok klon yang mempunyai perbedaan, baik pada fisiologi lateks, produksi, pola gugur daun, maupun ketahanan terhadap suatu jenis penyakit. Hasil penelitian Santoso (1990) menunjukkan bahwa komposisi perbandingan antara klon $L M$ dan $H M$ adalah $20: 80$ dapat mencapai produktivas rata-rata sebesar $1.994 \mathrm{Kg} / \mathrm{Ha}$.

Kondisi agroklimat dapat mempengaruhi fisiologi lateks, pertumbuhan, dan produksi tanaman karet (Oktavia \& Lasminingsih, 2010 ; Gohet et al., 2015; Junaidi et al., 2015). Sejumlah penelitian (Sumarmadji 2007; Junaidi et al., 2010; Siregar 2014; Purwaningrum et al., 2016) menyatakan bahwa unsur iklim terutama curah hujan menentukan fisiologi lateks dan produksi karet. Kadar Karet Kering ditentukan oleh beberapa faktor diantaranya jenis klon, musim, waktu penyadapan, suhu dan umur pohon, dan peningkatan sukrosa terjadi sejalan dengan peningkatan curah hujan dan seiring perkembangan daun yang sudah cukup matang untuk fotosintesis.

Kajian bidang antara karakter fisiologi dengan produksi lateks pada tanaman karet bermanfaat untuk menentukan tanaman yang diduga memiliki produktivitas tinggi (Jacob et al., 1989). Karakter fisiologi yaitu sukrosa, fosfat anorganik, dan thiol menjadi salah satu peubah pengamatan dalam menetapkan sistem eksploitasi dan menduga potensi produksi lateks. Konsep karaktreristik fisiologi klon telah diterapkan oleh Gohet et al. (2003) dan Lacote et al. (2013) yang didasarkan pada kondisi awal aktivitas metabolisme masing-masing klon.

Karakter fisiologi suatu klon diharapkan dapat digunakan untuk menentukan sistem eksploitasi yang tepat dan memprediksi potensi produksi sesuai dengan kemampuan klon. Apabila parameter fisiologi dan produksi lateks itu dirumuskan secara tepat dan dilaksanakan dengan akurat, maka profil dari suatu klon dapat digambarkan potensi produksinya. Informasi ini dapat menjadi pedoman kapan saat yang tepat aplikasi stimulan (Gohet et al., 2008) atau justru harus menurunkan konsentrasi atau frekuensi stimulan (Balit Sungei Putih, 2017). Lateks diagnosis (LD) selama ini diterapkan pada kebun swasta besar dan perkebunan negara dengan standar perawatan lebih baik dibandingkan perkebunan karet rakyat. Penelitian LD di kebun karet rakyat belum pernah dilaksanakan sebelumnya. Beberapa hal yang perlu dicatat bahwa kebun rakyat tidak melakukan perawatan yang standar dan pemanenan hasil tanpa stimulan. Oleh karena itu penelitian ini bertujuan untuk mengetahui hubungan fisiologi dengan produksi lateks klon GT1 dan waktu aplikasi stimulan yang tepat tanpa mengganggu kesehatan tanaman karet.

\section{BAHAN DAN METODE}

Bahan tanaman yang digunakan pada percobaan adalah klon GT1 dengan umur tanaman 20 tahun. Penelitian dilaksanakan di Desa Harapan, Kecamatan Sei Lapang, Kabupaten Langkat Sumatera Utara. Analisis fisiologi lateks dilaksanakan di Balai Penelitian Sungai Putih, Kecamatan Galang, Kabupaten Deli Serdang. Tanaman disadap pada kulit pulihan di posisi bidang sadap (B11.4), rata - rata lilit batang kulit 58,22 sampai $61,23 \mathrm{~cm}$. Sistem sadap yang digunakan oleh petani dalam memanen lateks adalah 1/2S D2, tanpa stimulant. Pengambilan sampel lateks dilaksanakan bulan Mei sampai Juli. Sampel diambil dari 25 tanaman dan diulang sebanyak tiga kali.

Penelitian ini menggunakan dua macam data yaitu data primer dan sekunder. Data primer merupakan percobaan lapangan menggunakan metode penelitian analisis statistik uji korelasi dan regresi. Uji korelasi digunakan untuk mengetahui keeratan hubungan antara variabel pengamatan, sedangkan uji regresi untuk mengetahui bentuk hubungan antara karakter fisiologi dengan produksi lateks. Sedangkan data sekunder merupakan data curah hujan selama 9 tahun (2009-2018) yang diperoleh dari BMKG Sampali Medan. 
Variabel pengamatan meliputi karakter fisiologi lateks yaitu kadar sukrosa, fosfat anorganik, dan thiol diukur dengan menggunakan contoh berupa serum lateks TCA (Trichloroacetic acid). Serum lateks dibuat dengan cara mencampur $1 \mathrm{~mL}$ lateks dengan $9 \mathrm{~mL}$ TCA.

\section{Analisis Fisiologi}

Kadar sukrosa diukur berdasarkan metode Dische (1962), yaitu menggunakan reaksi anthrone untuk menghasilkan turunan furfural yang berwarna hijau biru yang terabsorbsi pada panjang gelombang $\lambda$ 627. Pengukuran fosfat anorganik dilakukan dengan metode Taussky dan Shorr (1953), yaitu berdasarkan prinsip reaksi dengan molibdat menghasilkan kompleks Pi molibdat berwarna biru yang terabsorsi pada panjang gelombang $(\lambda) 750$. Nilai absorban diukur dengan spektrofotometer Beckham DU 650. Sedangkan pengukuran Thiol dilakukan metode McMullen (1960) yaitu diukur dari serum TCA berdasarkan prinsip reaksinya dengan asam dithiobis-nitrobenzoat (DTNB) untuk membentuk TNB yang berwarna kuning yang terabsorbsi pada ( $\lambda$ ) $421 \mathrm{~nm}$ dengan spektrofotometer Beckman DU 650.

\section{Analisis Data}

Analisis statistik dilakukan dengan menggunakan program Minitab ver.18 untuk mendapatkan nilai rata-rata pada masing-masing tanaman dari masingmasing peubah pengamatan, serta untuk mendapatkan nilai tengah, minimum, maksimum, simpangan baku, dan koefisien keragaman dari komponen hasil lateks.

\section{HASIL DAN PEMBAHASAN}

\section{Kondisi Agroklimat}

Kondisi curah hujan di lokasi penelitian selama 9 tahun yaitu dari tahun 2009 - 2018 menunjukkan variasi tiap bulannya disajikan pada Gambar 1 . Klasifikasi iklim menurut Oldeman menyatakan bahwa Bulan basah (BB) di wilayah Sumatera Utara khususnya kabupaten Langkat, jatuh bulan September, sedangkan bulan kering (BK) jatuh pada bulan Februari sampai April, bulan-bulan lainnya tergolong dalam kategori Bulan Lembab (BL) (Kertasapoetra \& Gunarsih, 2008).

Curah hujan tertinggi pada bulan September dan terendah pada bulan Februari. Curah hujan turun pada bulan Februari sampai April, kemudian naik kembali pada bulan Mei tetapi tidak setinggi curah hujan pada bulan September (Gambar 1). Pada bulan Mei (Gambar 1) curah hujan tinggi, dengan meningkatnya curah hujan hal ini sejalan dengan perkembangan kondisi daun tanaman dan hasil lateks pun meningkat. Pengaruh fisiologi dan hasil lateks bersamaan dengan sedikit banyaknya curah hujan, sinar matahari, suhu udara, kelembaban, tanah dan angin (Siregar, 2014).

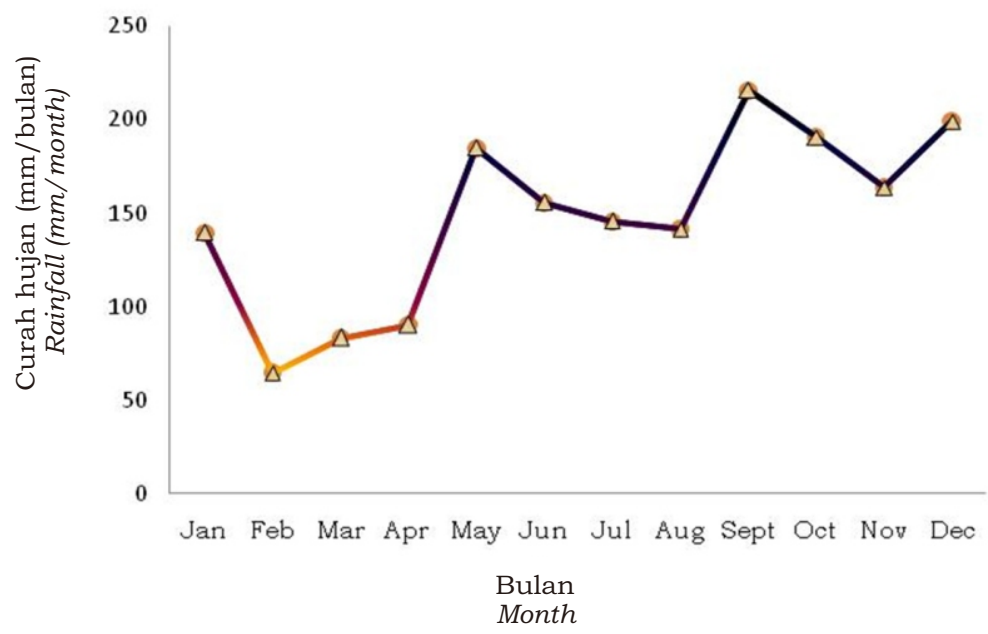

Gambar 1 Distribusi curah hujan tahun 2009-2018

Figure 1. Distribution of rainfall from 2009 - 2018 


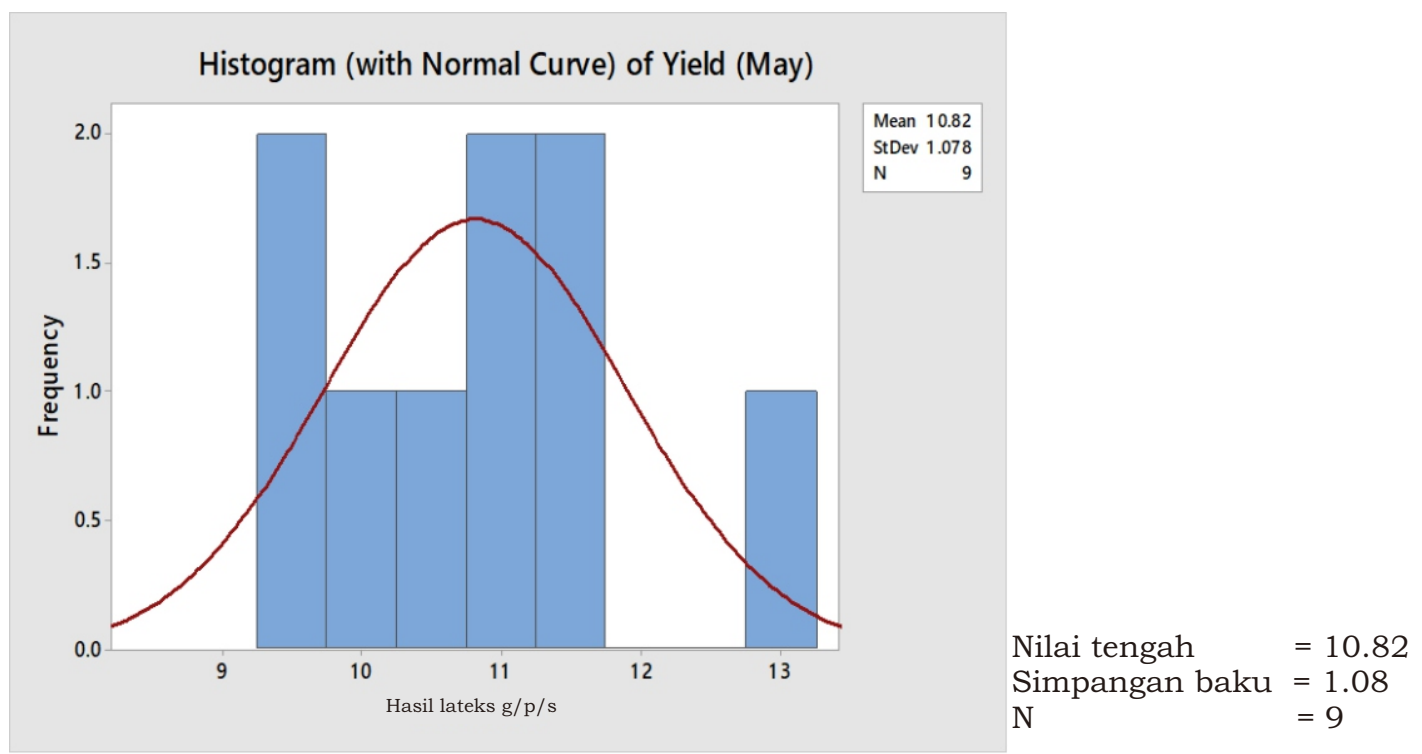

Gambar 2. Kurva frekuensi hasil lateks (g/p/s) pada klon GT 1 di bulan Mei Figure 2. The frequency curve for latex yield ( $(\mathrm{p} / \mathrm{p} / \mathrm{s})$ in GT 1 clones in May

Jika dibandingkan dengan hasil lateks pada bulan Mei, Juni dan Juli, di bulan Mei dan JuIi (Gambar 2 dan 4) produksi lateks lebih tinggi dibandingkan di bulan Juni (Gambar 3). Hal ini dikarenakan beberapa bulan sebelumnya curah hujan rendah (Gambar 1) tanaman mengalami gugur daun sehingga pada bulan tersebut tanaman mengalami kekurangan air yaitu di bulan Februari, Maret, dan April jumlah curah hujan rendah berturut - turut 64,70;
83,60 dan 90,50 $\mathrm{mm} /$ bulan, sedangkan pada bulan Mei jumlah curah hujan naik kembali yaitu $184,90 \mathrm{~mm} /$ bulan. Curah hujan dan hari hujan merupakan faktor iklim yang ikut mengalami penyimpangan dikarenakan perubahan iklim. Perubahan iklim dapat berdampak negatif maupun positif bagi tanaman karet di lapangan (Vinod et al., 2010). Secara umum tanaman karet dapat tumbuh dengan baik pada kisaran curah hujan 1500 - 4000 mm/tahun

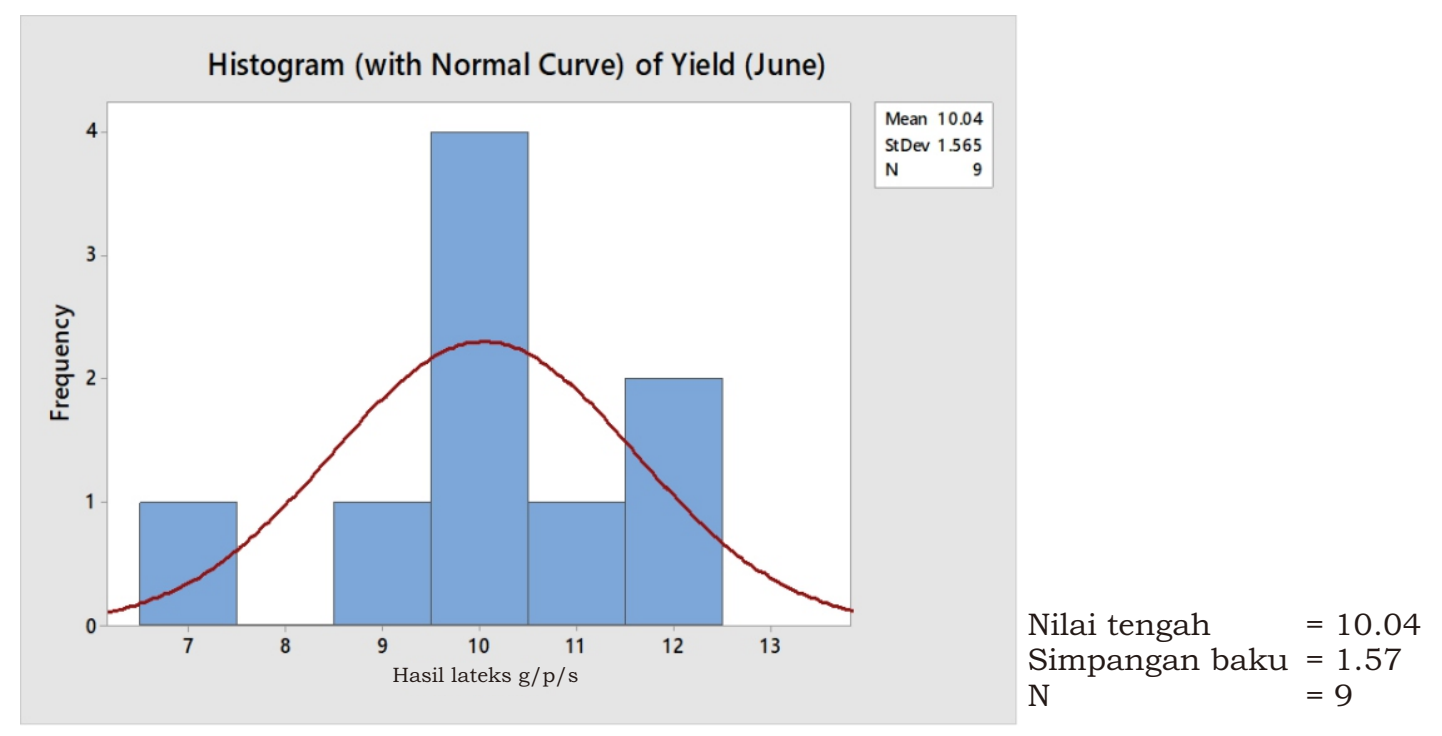

Gambar 3. Kurva frekuensi hasil lateks (g/p/s) pada klon GT 1 di bulan Juni Figure 3. The frequency curve for latex yield $(\mathrm{g} / \mathrm{p} / \mathrm{s})$ in GT 1 clones in June 
dengan distribusi merata. Curah hujan tahunan minimum yang masih memungkinkan tanaman karet dapat tumbuh dengan baik adalah sebesar 1500 $\mathrm{mm} /$ tahun (Dijkman, 1951; William et al., 1974). Jumlah Curah hujan 100 - 250 $\mathrm{mm} /$ bulan dapat mencukupi kebutuhan air pada tanaman karet (Vijayakumar, 2000). Kecukupan air di dalam tanaman karet untuk memenuhi fotosintesis, transpirasi, dan kebutuhan pembuluh lateks. Supporting air ke dalam pembuluh lateks akan meningkatkan tekanan turgor dan lama aliran lateks.

Pada bulan Juni - Juli Curah Hujan masih tetap tinggi (Gambar 1) sehingga proses fotosintesis tanaman dapat terlihat berlangsung secara maksimal dan berakibat pada tingginya produksi. Hal ini yang membuat produksi lateks tinggi di bulan Juli. Curah hujan cukup akan meningkatkan pertumbuhan dan produksi tanaman karet. Curah hujan yang rendah merupakan faktor penyebab tanaman karet menggugurkan daunnya sehingga terjadi penurunan laju aliran lateks. Kondisi tersebut menyebabkan hasil lateks tanaman karet menjadi rendah (Ardika et al., 2011). Hal ini menunjukkan bahwa dengan jumlah hari hujan dan suhu rendah pada suatu wilayah perkebunan karet dapat menjadi faktor pembatas produktivitas tanaman karet (Junaidi et al., 2015). Begitu sebaliknya jika ketersediaan air tanah cukup akan meningkatkan produktivitas tanaman karet. Jumlah hari hujan mempengaruhi ketersediaan air tanah yang akan terkait dengan metabolisme tanaman.

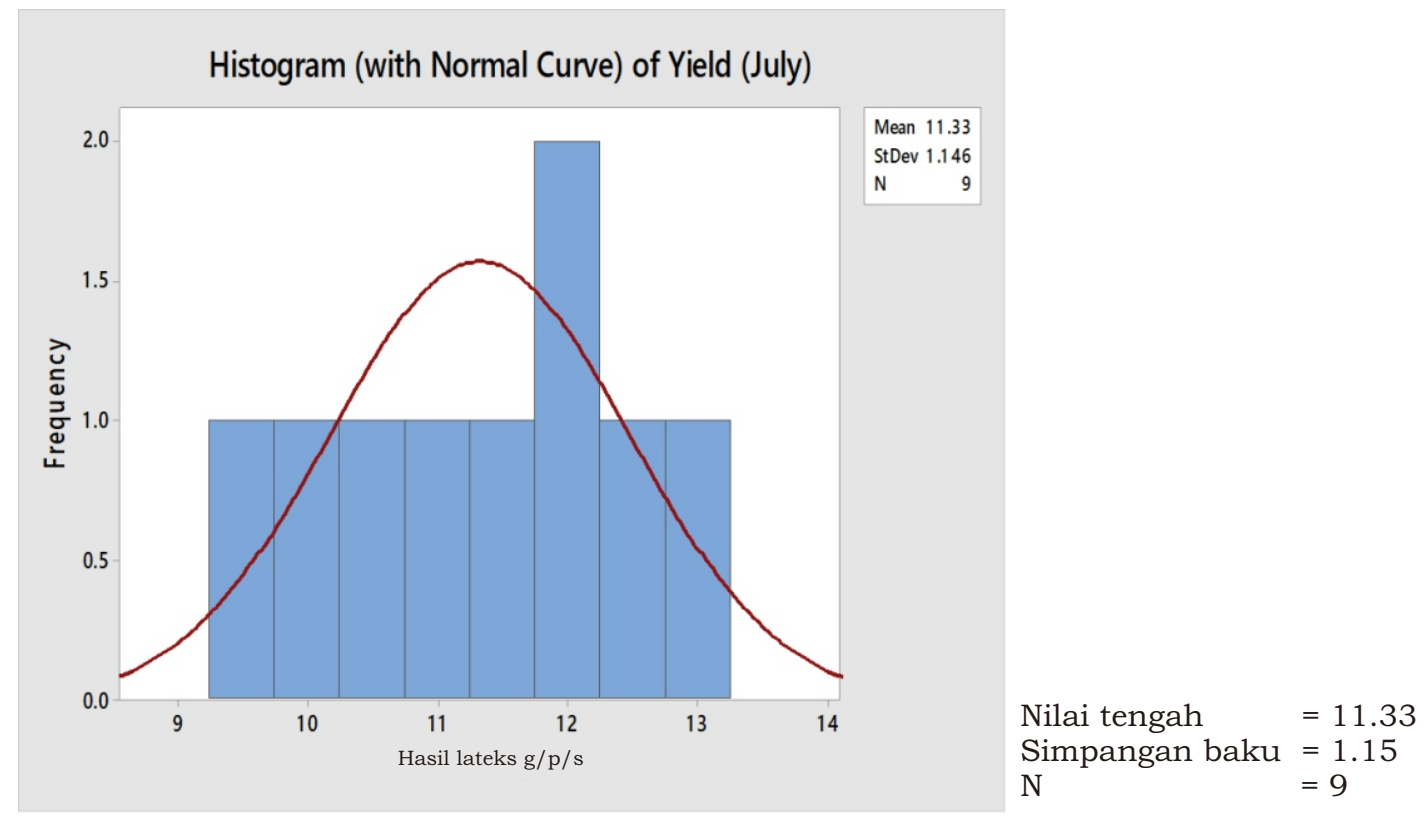

Gambar 4. Kurva frekuensi hasil lateks (g/p/s) pada klon GT 1 di bulan Juli Figure 4. The frequency curve for latex yield $(\mathrm{g} / \mathrm{p} / \mathrm{s})$ in GT 1 clones in July

\section{Karakter Fisiologis Klon GT1 Tanpa Stimulant}

Analisis statistik sederhana terhadap hasil pengamatan fisiologi dan produksi lateks diringkas pada Tabel 1. Pada Tabel 1 menunjukan bahwa karakteristik fisiologi lateks selama tiga bulan (Mei, Juni, dan Juli) terdapat adanya keragaman yang cukup besar diantara variable yang diamati.
Keragaman yang tertinggi ditemukan pada kadar Pi lateks, diikuti kadar thiol dan sukrosa yaitu berturut - turut 51,58\%, $26,00 \%$ dan $25,03 \%$. Hal ini menunjukkan bahwa kadar Pi lebih dominan dari kadar thiol dan sukrosa. Kadar Pi dalam lateks menunjukkan aktifitas metabolisme dalam pembuluh lateks (Jacob et al., 1989). 
Tabel 1. Ringkasan statistik sederhana analisis fisiologi dan produksi lateks pada klon karet GT1

Table 1. Summary of simple statistics on physiological analysis and production of latex of GT1 rubber clone

\begin{tabular}{|c|c|c|c|c|}
\hline \multirow{2}{*}{$\begin{array}{l}\text { Peubah } \\
\text { Variables }\end{array}$} & $\begin{array}{l}\text { Sukrosa } \\
\text { Sucrose }\end{array}$ & $\mathrm{Pi}$ & Thiol & \multirow{2}{*}{$\begin{array}{l}\text { Produksi karet }(\mathrm{g} / \mathrm{p} / \mathrm{s} \\
\text { Rubber yield }(\mathrm{g} / \mathrm{t} / \mathrm{t})\end{array}$} \\
\hline & \multicolumn{2}{|c|}{$(\ldots \ldots \ldots . . . m M \ldots . .)}$. & $(\mu \mathrm{M})$ & \\
\hline \multicolumn{5}{|l|}{ Mei } \\
\hline \multicolumn{5}{|l|}{ Nilai } \\
\hline Minimum & 4,25 & 0,55 & 0,14 & 9,43 \\
\hline Maksimum & 9,37 & 4,36 & 0,39 & 12,75 \\
\hline Nilai Tengah & 6,60 & 2,20 & 0,27 & 10,87 \\
\hline Simpangan Baku & 0,56 & 0,41 & 0,02 & 0,36 \\
\hline KK (\%) & 25,03 & 51,58 & 26,00 & 9,96 \\
\hline \multicolumn{5}{|l|}{ Juni } \\
\hline \multicolumn{5}{|l|}{ Nilai } \\
\hline Minimum & 4,25 & 0,55 & 0,14 & 6,67 \\
\hline Maksimum & 9,37 & 4,36 & 0,39 & 11,87 \\
\hline Nilai Tengah & 6,60 & 2,20 & 0,27 & 10,28 \\
\hline Simpangan Baku & 0,56 & 0,41 & 0,02 & 0,52 \\
\hline KK (\%) & 25,03 & 51,58 & 26,00 & 15,58 \\
\hline \multicolumn{5}{|l|}{ Juli } \\
\hline \multicolumn{5}{|l|}{ Nilai } \\
\hline Minimum & 4,25 & 0,55 & 0,14 & 9,33 \\
\hline Maksimum & 9,37 & 4,36 & 0,39 & 13,01 \\
\hline Nilai Tengah & 6,60 & 2,20 & 0,27 & 11,36 \\
\hline Simpangan Baku & 0,56 & 0,41 & 0,02 & 0,38 \\
\hline KK (\%) & 25,03 & 51,58 & 26,00 & 10,12 \\
\hline
\end{tabular}

Kadar Pi tinggi karena hanya sedikit Pi digunakan untuk mengubah sukrosa menjadi lateks (Herlinawati et al., 2013). Bahan utama dalam pembentukan lateks adalah kadar sukrosa. Kadar sukrosa yang diamati dalam tiga bulan menunjukkan adanya keragaman yang cukup rendah yaitu sebesar 25,03\% dibandingkan kadar $\mathrm{Pi}$ $(51,58 \%)$. Hal ini menunjukkan bahwa kadar sukrosa lateks belum digunakan sepenuhnya untuk menjadi lateks. Kadar sukrosa yang rendah menunjukkan bahwa metabolisme sangat intensif, namun juga berarti habisnya cadangan atau pasokan karbohidrat atau sebaliknya (Sumarmadji et al., 2008).

Hal ini sejalan dengan penyusunan pengelompokan status fisiologis. Balai Penelitian Sungei Putih (2017) menyatakan bahwa status tanaman di bulan Mei, kandungan sukrosa sedang, Pi sangat rendah, dan Thiol rendah. Kondisi tersebut menggambarkan tanaman masih belum aktif metabolisme (sub-optimum) dengan istilah teknis underexploitation. Kondisi yang sama juga terjadi pada Juni dan Juli dengan kandungan sukrosa yang tinggi dan $\mathrm{Pi}$ rendah. Rendah aktivitas metabolisme ditunjukkan dengan kandungan Pi yang masih rendah, dan rendah aktivitas ini konversi sukrosa menjadi karet rendah. Kandungan sukrosa di dalam lateks yang medium menunjukkan konversi sukrosa menjadi karet berjalan lambat. Kandungan karet masih dikategorikan rendah karena masih di bawah $19 \mathrm{~g} / \mathrm{p} /$ sadap.

Berdasarkan status fisiologis tanaman, maka stimulansia dapat diaplikasikan mulai bulan Juni. Frekuensi aplikasi stimulansia adalah 2 minggu sekali karena klon ini termasuk pada metabolisme rendah. Namun demikian, aplikasi tersebut harus memperhatikan kondisi daun, apakah perkembangan daun sudah sempurna atau masih sebagian muda. Stimulansia dapat meningkatkan aktivitas metabolisme ditandai dengan meningkatnya kandungan Pi di dalam lateks. Peningkatan aktivitas biosintesis lateks akan mempercepat konversi sukrosa menjadi karet, dan pada batas tertentu akan menyebabkan turunnya kandungan sukrosa di dalam lateks. Selain 
$\mathrm{Pi}$, thiol biasa akan meningkat dengan pemberian stimulan. Fungsi thiol sebagai antioksidan, sehingga stress oksidatif sebagai akibat aktifnya metabolism dalam sel dapat ditekan (Jacob et al., 1989). Kadar tiol yang rendah menunjukkan belum intensifnya eksploitasi (Gohet, 2008).

Hasil uji korelasi antara masingmasing peubah yang diamati selama tiga bulan disajikan pada Tabel 2. Dari hasil analisis korelasi menunjukkan bahwa peubah fisiologi lateks berkorelasi tidak nyata pada bulan Mei, Juni dan Juli. Kecuali korelasi antara sukrosa dan produksi lateks pada bulan Juni berbeda nyata dan berkorelasi negatif, artinya kadar sukrosa yang tinggi karena belum banyak digunakan untuk menghasilkan karet, begitu juga sebaliknya.

Apabila aktifitas biosintesis karet lebih aktif maka semakin banyak sukrosa yang digunakan untuk menghasilkan karet, sehingga kandungannya menjadi lebih rendah dan produksi karet meningkat. Kadar sukrosa lateks tinggi yang terukur dalam suatu pengamatan tidak memiliki arti langsung sebagai gambaran tingginya produksi. Kondisi demikian justru bisa mengindikasikan produksi rendah karena sukrosa mungkin belum dapat disintesis menjadi lateks. Produksi lateks dan pertumbuhan dapat berkompetisi dengan kuat dalam hal penggunaan lateks (Gohet et al., 2006).

Tabel 2. Matriks koefisien korelasi antara fisiologi lateks dengan komponen hasil lateks Table 2. Correlation coefficient matrix between latex physiology and latex yield component

\begin{tabular}{lclc}
\hline \multicolumn{1}{c}{$\begin{array}{c}\text { Peubah } \\
\text { Variable }\end{array}$} & $\begin{array}{c}\text { Produksi }(\mathrm{g} / \mathrm{p} / \mathrm{s}) \\
\text { Yield }(\mathrm{g} / \mathrm{t} / \mathrm{t})\end{array}$ & $\begin{array}{l}\text { Sukrosa } \\
\text { Sucrose } \\
(\mathrm{mM})\end{array}$ & $\begin{array}{l}\text { Thiol } \\
\text { Thiol } \\
(\mathrm{mM})\end{array}$ \\
\hline \multicolumn{4}{c}{ Bulan Mei } \\
\hline Sukrosa & $-0,50 \mathrm{tn}$ & $-0,15 \mathrm{tn}$ \\
$\mathrm{Pi}$ & $-0,15 \mathrm{tn}$ & $-0,19 \mathrm{tn}$ & \\
Tiol & $-0,22 \mathrm{tn}$ & $-0,24 \mathrm{tn}$ & \\
\hline \multicolumn{4}{c}{ Bulan Juni } \\
\hline Sukrosa & $-0,72^{* *}$ & $0,19 \mathrm{tn}$ & $-0,15 \mathrm{tn}$ \\
$\mathrm{Pi}$ & $-0,12 \mathrm{tn}$ & $-0,24 \mathrm{tn}$ & \\
Tiol & $-0,39 \mathrm{tn}$ & $-0,15 \mathrm{tn}$ \\
\hline \multicolumn{5}{c}{ Bulan Juli } \\
\hline Sukrosa & $-0,22 \mathrm{tn}$ & $-0,24 \mathrm{tn}$ & \\
Tiol & $0,04 \mathrm{tn}$ & $-0,24 \mathrm{tn}$ & \\
\hline
\end{tabular}

\section{KESIMPULAN}

Dari hasil penelitian ini disimpulkan bahwa hasil koefisien korelasi menunjukkan kadar sukrosa berkorelasi negatif dengan produksi lateks, dimana kadar sukrosa tinggi produksi lateks rendah begitu sebaliknya. Koefisien keragaman (KK) menunjukkan bahwa terdapat respon yang berbeda tiap bulannya, dimana pada bulan
Mei dan Juli hasil lateks KK lebih rendah berturut -turut yaitu sebesar 37,49\% dan $34,50 \%$ sedangkan pada bulan Juni produksi lateks lebih tinggi $57,25 \%$. Hal ini menunjukkan bahwa pada bulan Juni produksi lateks dipengaruhi oleh fisiologi lateks lebih besar $(57,25 \%)$ dan kondisi tersebut (Juni) menjadi waktu yang tepat untuk memulai aplikasi stimulansia. 


\section{UCAPAN TERIMA KASIH}

Penulis mengucapkan terimakasih kepada Kementerian Riset, Teknologi, dan Pendidikan Tinggi Republik Indonesia melalui penelitian Hibah Kompetitif Nasional dan kepada Balai Penelitian Karet Sungei Putih atas bantuan fasilitas sarana peralatan laboratorium.

\section{DAFTAR PUSTAKA}

Ardika, R., Cahyo A.N., \& Wijaya, T. (2011). Dinamika gugur daun dan produksi berbagai klon karet kaitannya dengan kandungan air tanah. Jurnal Penelitian Karet, 29(2), 102-109. Doi : 10.22302/ ppk.jpk.v29i2.242.

Balai Penelitian Sungei Putih. (2017). Laporan lateks diagnosis (LD) kebunkebun PT. Perkebunan Nusantara III (Persero). Sumatera Utara, Indonesia : Balai Penelitian Sungei Putih, Pusat penelitian Karet.

Bricard, P., \& Nicolas, D. (1989). Possibility of the use of physiological parameters of lateks in early selection, In $\mathrm{d}^{\prime}$ Auzac.,J., Jacob, J.L., \& Chrestin, H. Physiology of rubber tree. Florida, USA : Boca Raton, CRC Press.

Dijkman, M.J. (1951). Hevea. Thirty years of research in the Far East. Florida, USA : University of Miami.

Dische, Z.M. (1962). Carbohydrate Chemistry. New York, USA : Academic Press.

Gaspersz, \& Vincent. (1992). Manajemen produktivitas total strategi peningkatan produktivitas bisnis global. Jakarta, Indonesia : PT Gramedia Pustaka Utama.

Gohet, E., Prevot, J.C., Eschbach, J.M., \& Clement, A. (1996). Clones, growth and stimulation : Latex production factors. Plantation, Recherche, Developpement, 3, 30-38.
Gohet, E., Chantuma, P., Lacote, R., Obouayeba, S., Dian, K., ClementDemange, A., Kurnia, D., \& Eschbach, J.M. (2003). Latex clonal typology of Hevea brasiliensis : physiological modelling of yield potential and clonal response to ethephon stimulation. IRRDB Workshop on Exploitation Technology (p. 199-216). Kottayam, India: IRRDB.

Gohet, E., Scomparin, C., Cavaloc, E., \& Balerin, Y. (2008). Influence of ethephon stimulation on latex physiological parametes and consequences on latex diagnosis implementation in rubber agroindustry. IRRDB Workshop on Latex Harvesting Technologies (11p). Kuala Lumpur, Malaysia : IRRDB \& Malaysia Rubber Board.

Herlinawati, E., \& Kuswanhadi. (2013). Aktivitas metabolisme beberapa klon karet pada berbagai frekuensi sadap dan stimulas. Jurnal Penelitian Karet, 31 ( 2 ), $\quad 110-116$. D o i : 10.22302/ppk.jpk.v31i2.138.

Jacob, J.L., Prevot, J.C., Lacote, R., \& Gohet, E. (1989). The biological mechanisme controlling Hevea brasiliensis rubber yield. Plantation, Resherche, Developppment, 5(1), 5-17.

Jacob, J.L., Prevot, J.C., Roussel, D., \& Lacote, R. (1989). Yeild limiting factors, latex physiological parameters, latex diagnosis and clonal physiological. in d'Auzac, J., Jacob, J.L., \& Chrestin, H. Physiological of rubber tree latex. Boca Raton, Florida, USA : CRC Press.

Junaidi, Sumarmadji, \& Atminingsih. (2010). Testing of the system of exploitation Expex-315 clone PB 260. Rubber Research Journal, 28(2), 41-56.

Junaidi, Sembiring, Y.R., \& Siregar, T.H.S. (2015). Pengaruh perbedaan letak geografi terhadap pola produksi tahunan tanaman karet: Faktor penyebab perbedaan pola produksi tahunan tanaman karet. Warta Perkaretan, 34(2), 137-146. Doi : 10.22302/ppk.wp.v34i2.254. 
Kertasapoetra, I.G. (2008). Klimatologi: pengaruh iklim terhadap tanah dan tanaman. Jakarta, Indonesia: BUMI AKSARA.

Lacote, R., Doumbia, A., Obouayeba, S., \& Gohet, E. (2013). Sustainable rubber production through good latex harvesting practices: stimulation based on clonal latex functional typology and tapping panel management. IRRDB Workshop on Latex Harvesting Technology (18p.). Binh Duong, Vietnam : RRIV \& IRRDB.

McMullen, A.I. (1960). Thiol of low moleculer weight in Hevea brasiliensis latex. Biochimica et Biophysica Acta, 41(1), 152-154. Doi : 10.1016/00063002(60)90383-8.

Purwaningrum, Y., Asbur, Y., Hanum, C., \& Siregar, T.H.S. (2016). Exploitation system based on development dynamic of clones BPM 1 in North Sumatera, Indonesia. International Journal of Science and Research Methodology, 4(4), 261-273.

Siregar, T.H.S., Junaidi, U., Sumarmadji, Siagian, N., \& Karyudi. (2008). Perkembangan penerapan rekomendasi sistem eksploitasi tanaman karet di perusahaan besar negara. Prosiding Lokakarya Nasional Agribisnis Karet 2008. Yogyakarta, Indonesia : Pusat Penelitian Karet.

Siregar, T.H.S. (2014). Pola musiman produksi dan gugur daun pada Klon pb 260 dan RRIC 100. Jurnal Penelitian Karet, 32(2), 88 - 97. Doi : 10.22302/ppk.jpk.v32i2.155.

Santoso, B. (1990). Perbaikan pola produktivitas tanaman karet melalui komposisi klon berimbang di perkebunan. Warta Perkaretan, 13(1), 31-42.
Sumarmadji, Siswanto, \& Yahya, S. (2004). Penggunaan parameter fisiologi lateks untuk penentuan sistem eksploitasi tanaman karet (Hevea brasiliensis). Jurnal Penelitian Karet 2004, 21(1), 4152 .

Sumarmadji. (2007). Optimized exploitation system for various rubber clones. Proceedings of International Rubber Conference and Exhibition (p. 169-183). Bali, Indonesia : IRRI \& IRRDB.

Sumarmadji, Atminingsih \& Karyudi. (2008). Konsep penyadapan klon slow stater dengan stimulan gas etilen dan irisan pendek ke arah atas sejak awal sadap. Prosiding Lokakarya Agribisnis Karet 2008 (p. 1375 - 1386). Yogyakarta, Indonesia : Pusat Penelitian Karet.

Sumarmadji. (2011). Sistem eksploitasi tanaman berdasarkan tipologi klon (QS dan SS) dan alternatif sistem eksploitasi lainnya (Expex-315 dan SS-CUT). Workshop Penggunaan Klon Unggul Baru dan Sistem Eksploitasi Tanaman Karet yang Tepat dalam Menghadapi Peningkatan Karet Alam Dunia. Medan, Indonesia : Pusat Penelitian Karet.

Taussky. H., \& Shorr. E. (1953). A micro colorimetric methods for the determination of inorganic phosphorus. Biol. Chem., 202, 675685.

Vijayakumar, K.R., Chandrashekar, T.R., \& Philip, V. (2000). Agroclimate. In :George, P.J., \& Jacob, C.K. (eds). Natural Rubber : Agromanagement and Crop. Kerala, India : Rubber Research Institute of India.

Williams, C.N., \& Joseph, K.T. (1974). Climate, soil, and crop production in the humid tropics. Oxford, UK : University Press London. 
Woelan, S., Sayurandi, \& Pasaribu, S.A. (2013). Karakter fisiologi, anatomi,pertumbuhan dan hasil lateks klon IRR Seri 300. Jurnal Penelitian Karet, 31(1), 1-12. Doi : 10.22302/ppk.jpk.v31i1.128.

Woelan, S., Suhendry, Daslin, A., \& Anzar, R. (1999). Karakteristik klon anjuran rekomendasi 1999-2001. Warta Pusat Penelitian Karet, 18(1-3).
Vinod, K.K., Meenattoor, J.R., Reddy, Y.A.N., Priyadarshan, P.M. \& Chaudhuri, D. (2010). Ontogenetic variations in flush development are indicative of low temperature tolerance in Hevea brasiliensis clones. Annals of Forest Research., 53(2), 95-105. 